\title{
Energy requirements during weight loss and weight maintenance of two morbidly obese cats
}

\author{
Ronald Jan Corbee \\ From Animal Obesity - causes, consequences and comparative aspects \\ Uppsala, Sweden. 14-16 June 2015
}

\section{Introduction}

Two morbidly obese cats were presented at the weight management clinic. The first cat was a domestic shorthair with a body weight of $10.82 \mathrm{~kg}$. The second cat was a domestic shorthair with a body weight of $13.42 \mathrm{~kg}$. At presentation, both cats suffered from obstipation, and dull hair coat.

\section{Objectives}

To achieve weight loss to target weight and to maintain target weight for at least 2 years and to evaluate energy requirements during weight loss in morbidly obese cats.

\section{Methods}

The two cats were put on a weight reduction diet with high protein (34\% on dry matter basis) and high fiber (14.1\% on dry matter basis) content at $0.8 \times R E R$ (resting energy requirement). The amount of food was adjusted according to the progress of weight loss, monitored by 2 -weekly body weight measurements. The amount of food eaten and recommended were recorded.

\section{Results}

Both cats reached their target weight of $3.8 \mathrm{~kg}$ and $4.5 \mathrm{~kg}$, respectively. Both cats maintained their target weight for two years with minor adaptions of food intake during weight loss and weight maintenance phase. Constipation and dull hair coat resolved quickly.

\section{Conclusions}

Weight loss by reducing food intake and by the use of a high protein, high fiber diet are very effective, even in morbidly obese cats. Client communication and proper follow up are key factors for successful obesity management. Metabolic adaptations occur during weight loss

Correspondence: r.j.corbee@uu.nl

Department of Clinical Science, Utrecht University, Utrecht, Netherlands and weight maintenance, resulting in altered enery requirents, which therefore requires lifelong follow up and adaptations in food intake.

Published: 25 September 2015

\section{doi:10.1186/1751-0147-57-S1-P3}

Cite this article as: Corbee: Energy requirements during weight loss and weight maintenance of two morbidly obese cats. Acta Veterinaria Scandinavica 2015 57(Suppl 1):P3.
Submit your next manuscript to BioMed Central and take full advantage of:

- Convenient online submission

- Thorough peer review

- No space constraints or color figure charges

- Immediate publication on acceptance

- Inclusion in PubMed, CAS, Scopus and Google Scholar

- Research which is freely available for redistribution

Submit your manuscript at www.biomedcentral.com/submit
() Biomed Central 